IZA DP No. 9453

Globalization, Technological Change and Labor

Demand: A Firm Level Analysis for Turkey

Elena Meschi

Erol Taymaz

Marco Vivarelli

October 2015 


\title{
Globalization, Technological Change and Labor Demand: A Firm Level Analysis for Turkey
}

\author{
Elena Meschi \\ Università Ca Foscari \\ Erol Taymaz \\ Middle East Technical University \\ Marco Vivarelli \\ Università Cattolica del Sacro Cuore, \\ SPRU, University of Sussex and IZA
}

\section{Discussion Paper No. 9453}

October 2015

\author{
IZA \\ P.O. Box 7240 \\ 53072 Bonn \\ Germany \\ Phone: +49-228-3894-0 \\ Fax: +49-228-3894-180 \\ E-mail: iza@iza.org
}

Any opinions expressed here are those of the author(s) and not those of IZA. Research published in this series may include views on policy, but the institute itself takes no institutional policy positions. The IZA research network is committed to the IZA Guiding Principles of Research Integrity.

The Institute for the Study of Labor (IZA) in Bonn is a local and virtual international research center and a place of communication between science, politics and business. IZA is an independent nonprofit organization supported by Deutsche Post Foundation. The center is associated with the University of Bonn and offers a stimulating research environment through its international network, workshops and conferences, data service, project support, research visits and doctoral program. IZA engages in (i) original and internationally competitive research in all fields of labor economics, (ii) development of policy concepts, and (iii) dissemination of research results and concepts to the interested public.

IZA Discussion Papers often represent preliminary work and are circulated to encourage discussion. Citation of such a paper should account for its provisional character. A revised version may be available directly from the author. 


\section{ABSTRACT \\ Globalization, Technological Change and Labor Demand: A Firm Level Analysis for Turkey*}

This paper studies the interlinked relationship between globalization and technological upgrading in affecting employment and wages of skilled and unskilled workers in a middle income developing country. It exploits a unique longitudinal firm-level database that covers all manufacturing firms in Turkey over the 1992-2001 period. Turkey is taken as an example of a developing economy that, in that period, had been technologically advancing and becoming increasingly integrated with the world market. The empirical analysis is performed at firm level within a dynamic framework using a $2+2$ equations model that depicts the employment and wage trends for skilled and unskilled workers separately. In particular, the System Generalized Method of Moments (GMM-SYS) procedure is applied to a panel dataset of about 15,000 firms. Our results confirm the theoretical expectation that developing countries face the phenomena of skill-biased technological change and skill-enhancing trade, both leading to increasing the employment and wage gap between skilled and unskilled workers. In particular, a strong evidence of a relative skill bias emerges: both domestic and imported technologies increase the relative demand for skilled workers more than the demand for the unskilled. "Learning by exporting" also appears to have a relative skill biased impact, while FDI imply an absolute skill bias.

JEL Classification: $\quad 033$

Keywords: skill-biased technological change, international technology transfer, GMM-SYS

Corresponding author:

Marco Vivarelli

Istituto di Politica Economica

Università Cattolica

Largo Gemelli 1

I-20123 Milano

Italy

E-mail: marco.vivarelli@unicatt.it

\footnotetext{
* The authors would like to thank Dr. Ilina Srour (American University of Beirut) for her excellent research assistance.
} 


\section{INTRODUCTION}

Many developing countries (DCs) in the 1980s underwent structural changes, where they moved from import substitution to liberalization and export-oriented strategies. Opening their doors to international trade, DCs were faced with two major growth effects. On the one hand, liberalization has involved a static effect pertaining to inter-sectoral transfer of resources, mainly due to changes in the relative price structure. On the other hand, trade openness has fostered a dynamic effect emerging from the productivity growth due to increased exposure of local firms to competition (both foreign and domestic), increased technological imports embodied in capital and intermediate goods, and to the transfer of knowledge through licensing, patents and other rights (see Rodrik, 1995). The integration in the global market thus created new opportunities for developing countries that are now able to attract foreign investors, foreign capital and foreign technology.

However, globalization and technological upgrading have also implied important challenges for DCs' labor markets (see Stiglitz, 2002). On the one hand, new technologies were often characterized by a labor-saving nature, involving increasing unemployment, at least in some sectors such as traditional manufacturing. On the other hand, the productivity gains brought about by globalization and technological upgrading were often coupled with a growing gap between the employment and the wages of skilled and unskilled workers. Indeed, the standard Heckscher Ohlin and Stolper Samuelson predictions that trade liberalization would reduce the skill premium in developing countries have not been supported by empirical evidence. In this respect, the skill-biased technological change (SBTC) hypothesis is better able to describe the reality of shifting relative employment demand towards more skilled labor.

This paper investigates these issues, using detailed firm-level data on Turkish manufacturing sector over the period 1992-2000 (Annual Manufacturing Industry Statistics by the Turkish Statistical Institute, TurkStat). In particular, we test how international openness and technological change (both domestic and imported) affected the Turkish labor market both from a quantitative and a qualitative point of view. Moreover, we investigate the impact of globalization and technology on the wage gap between skilled and unskilled labor.

Turkey - over the investigated period - presents itself as a suitable candidate for testing the interlinked relationship between globalization and technology adoption in affecting the labor demand. First, trade openness has increased substantially in Turkey over the period analyzed, due to a trade liberalization process initiated in the 1980s and intensified during the 1990s. Second, Turkey is a country with significant trade flows with developed countries, especially the EU, which make it a net technology importer that relies on technology import as a main source for technological upgrading. Moreover, being a rather developed middle-income country, it possesses sufficient capacity both to develop domestic innovations and to absorb new technologies (see Cohen and Levinthal, 1990).

The novelty of this study in comparison with previous empirical literature on the subject is that it is performed at firm level within a dynamic framework using a two-equation model that depicts the employment and wages trends for skilled and unskilled workers separately. More specifically, it allows understanding the forces driving the movements in employment and wages of both types of workers. In fact, a positive shift of the skill-ratio could be the result of the reduction of unskilled workers only, the increase of skilled workers only, a faster increase in the numbers of skilled workers, or a combination of these movements. A single equation framework cannot capture these different dynamics; therefore, having two equations for both employment and wages can provide a more 
thorough understanding of the nature of the possible labor-saving and skill-biased nature of the impact of globalization and technological upgrading. Moreover, separately analyzing the effect of trade and technology on employment and wages of skilled and unskilled workers, we are able to distinguish between quantity and price effect. Finally, an important novelty of this paper is the availability for a middle-income country of a rich firm-level dataset that contains detailed information on firms' technological upgrading and trade openness. In particular, our data allow distinguishing between disembodied and embodied technological change and between domestic innovation capacity and technological transfer from abroad.

The remainder of the paper is organized as follows: Section 2 surveys existing literature on the quantitative and qualitative employment impact of technology and analyses the role of trade induced technological change on the relative demand for skilled labor developing countries. Section 3 describes the data and provides some descriptive statistics. Section 4 presents the empirical model and the econometric specification, while in section 5 we present and discuss the results obtained. Section 6 concludes with some final remarks.

\section{THE IMPACT OF TECHNOLOGY AND TRADE ON EMPLOYMENT AND SKILLS}

In this section we start discussing the relevant literature devoted to study the impact of technology on employment and skills (Section 2.1). Then, we relate technological upgrading with globalization, focusing on their overall effects on the labor-markets of the DCs (section 2.2).

\subsection{QuANTITATIVE AND QUALITATIVE EMPLOYMENT IMPACT OF TECHNOLOGY}

By definition, technological progress implies the possibility to produce the same amount of output with less workers. However, the conventional wisdom in economic theory states that technological unemployment is a temporary circumstance, which can be automatically compensated by market force mechanisms that work to reintegrate the employees who had lost their jobs. These mechanisms came to be known as the "compensation theory", using the terminology presented by Karl Marx in his discussions on large-scale industry and the introduction of machinery (see Marx 1961: Chap. 15). Six compensation mechanisms work to offset technology's labor-saving effects through: (1) additional employment in the capital goods sector where new machines are being produced (2) decreases in prices resulting from lower production costs on account of technological innovations, (3) new investments made using extra profits due to technological change, (4) decreases in wages resulting from price adjustment mechanisms and leading to higher levels of employment, (5) increases in income resulting from redistribution of gains from innovation, and (6) new products created using new technologies (for a detailed analysis see Vivarelli, 1995; Pianta, 2005).

However, measuring the extent and actual effectiveness of these compensation mechanisms and assessing the final quantitative impact of technology on overall employment is not a straightforward exercise and has long been a subject of a controversial debate among economists (see Vivarelli, 2013 
and 2014). In particular, low demand and capital/labor substitution elasticities, attrition, pessimistic expectations and delays in investment decisions may involve that compensation can only be partial.

The discourse on compensation mechanisms and their functioning has often taken place within the context of developed countries. Overall, the empirical literature on the subject has pointed out that product innovation tends to be labor friendly, while process innovation reveals to be labor-saving; moreover, the job creating effect of innovation is far more obvious in high-tech sectors and new services rather than in low-tech manufacturing and traditional services (for recent studies see Bogliacino and Pianta, 2010; Lachenmaier and Rottman, 2011; Bogliacino and Vivarelli, 2012; Bogliacino, Piva and Vivarelli, 2012; Feldmann, 2013). Therefore, the validity of the compensation theory becomes even more questionable in DCs, where process innovations dominate product innovations and where mature manufacturing sectors and traditional services represent the bulk of their economic structure ${ }^{1}$.

Another important stream of literature has shown that the relationship between technology and employment has a qualitative aspect as well, giving rise to the notion of Skill Biased Technological Change (SBTC). The concept of SBTC, first developed by Griliches (1969) and Welch (1970), is based on the hypothesis of capital-skill complementarity, and suggests that employers' increased demand for skilled workers is driven by new technologies that are penetrating into modernized industries, and which only workers with a higher level of skill can operate (see Machin, 2003; Piva and Vivarelli, 2009).

The literature on SBTC remains mainly empirical, where many studies indicate that SBTC has gained momentum during the past three decades due to the surge in information technology and spread in computers (Pianta, 2005). The first to explore SBTC empirically were Berman, Bound and Griliches (1994) who provided evidence for the existence of strong correlations between within industry skill upgrading and increased investment in both computer technology and R\&D in the U.S. manufacturing sector between 1979 and 1989. Autor, Katz and Krueger (1998) also show that the spread of computer technology in the US since 1970 can in fact explain as much as 30 to 50 percent of the increase in the growth rate of relative demand for skilled labor. Empirical studies supporting SBTC were conducted for several other OECD countries, such as, for example, UK (see Machin 1996, Haskel and Heden, 1999), France (see Mairesse, Greenan, and Topiol-Besaid, 2001, Goux and Maurin, 2000), Germany (see Falk and Seim, 1999), Italy (see Piva and Vivarelli, 2004), and Spain (see Aguirregabiria and Alonso-Borrego, 2001). Additionally, Machin and Van Reenen (1998) provide evidence of SBTC in a cross-country study on seven OECD countries and again assert a positive relation between R\&D expenditure and relative demand for skilled workers.

\subsection{Trade and Technological Change in Developing Countries}

Turning our attention to the impact of trade over labor demand in a DC, the recent literature has recognized the failure of the traditional trade theory (expressed in the Heckscher-Ohlin (HO) and the

\footnotetext{
1 For examples on the ineffectiveness of compensation mechanisms in developing countries, see Karaomerlioglu and Ansal, 1999. They explain for instance that the first compensation mechanism concerned with employment in the capital goods sector is mostly inexistent in developing countries since they generally import their technologies rather than produce them locally. Therefore, the application of new technologies will not create substantial employment in the technology supplier sectors. The compensation mechanism through decrease in wages might also be ineffective in developing countries since wages there are already low. Therefore, the expectation that reduction in wages will help in increasing labor demand is not valid in the case of developing countries.
} 
Stolper-Samuelson (SS) theorems) in explaining the increase in income inequality experienced by many DCs as a consequence of trade openness ${ }^{2}$.

In particular, these new approaches relax the fundamental HOSS assumption of technological homogeneity among countries and consider instead that technological levels differ substantially between developed and developing countries and argue that trade openness facilitates technology diffusion from North to South ${ }^{3}$. Even though developed countries do not usually transfer their best state-of-the-art technologies, it remains safe to assume that they do bring about significant relative upgrading to the traditional modes of production of local industries in DCs. Therefore, the final impact of trade on employment and skill premium is highly dependent on the skill-intensity embodied in the transferred technology. Since R\&D activities are generally quite limited in DCs, trade liberalization plays a crucial role in opening the door to various channels of technology transfer, which act as the primary means of technological upgrading (see Dosi and Nelson, 2013).

The idea that DCs, through trade, import technologies that are relatively more skill-intensive than those in use domestically, was first proposed by Robbins (1996 and 2003) that called this hypothesis "skill-enhancing trade (SET)". In particular, Robbins argues that DCs' imports mainly consist of capital goods, which embody technologies that are surely more advanced and skill-biased than those originally used in the local economies. Moreover, in those DCs that are shifting from importsubstitution economic systems to trade liberalization systems, strategies that hampered the adoption of foreign technologies no longer exist, and increased market competition leads to an increased adoption of modern, skill-intensive technologies. Consequently, the liberalized DCs appear to follow a skill-intensive biased trend similar to that observed in developed countries (see Robbins 1996; Berman and Machin, 2000 and 2004).

There are additional channels through which trade liberalization favors technological upgrading. The first one is by increasing the international flows of capital goods that provide local firms access to new embodied technologies and create opportunities for reverse engineering (Acemoglu, 2003 and Coe and Helpman, 1995). A second mechanism acts through the export channel. The idea is that exporting (especially to high-income countries) requires quality upgrades that are skill-intensive (Verhoogen, 2008) and thus requires adopting newer and better technologies (Bustos, 2009). Yeaple (2005) also showed that increased export opportunities make the adoption of new technologies profitable for more firms, thus increasing the aggregate demand for the skilled labor and the skill premium. Overall, the revealed skill-biased impact of exporting may be related to the so-called "learning by exporting" effect: engaging in export activities encourages hiring more skilled than unskilled workers as a response to a more sophisticated foreign demand and a tougher international competition.

Other channels are the direct trade in knowledge through technology purchase or licensing and the FDI. Obviously enough, FDI can be an important conduit for the transfer of technology (see, for example, Blomström and Kokko, 1998), which in turns requires an upgrading of the skills of the local labor force.

\footnotetext{
2 HO-SS theory in fact predicts that trade liberalization would reduce inequality in DCs, since they would specialize in the production and export of unskilled-labor intensive goods, given that unskilled labor is the abundant factor in those countries. This will in turn raise the real income of the unskilled labor and thus decrease the wage gap between skilled and unskilled labor.

${ }^{3}$ For a thorough survey on the literature on international diffusion of technology, see Keller (2004).
} 
Empirically, the evidence on the impact of trade-induced technological change on employment and the relative demand for skills tends to support the hypotheses discussed above ${ }^{4}$. First, several studies ${ }^{5}$ documented an increase in the share of skilled workers and their relative wage within fairly narrowly defined industry categories also in DCs, which can be interpreted as an evidence in favor of skilledbiased technological change. Similarly, Berman and Machin (2000 and 2004) observed that the industries that upgraded their technologies and increased their demand for skilled labor in the DCs during the 1980s are the same industries that underwent this process in the US during the '60s and '70s. They conclude that technologies are transferred from developed to developing countries where they are having the same skill-upgrading effect. In a similar vein, Gallego (2012) shows that the patterns of skill upgrading in Chile and the US are significantly correlated and his findings suggest that the increase in the relative demand for skilled workers in Chile is a consequence of international transmission of skill-upgrading technologies from developed countries, in particular the US.

Other papers have studied more explicitly the link between imported technology and the relative demand for skilled labor and have generally confirmed the skill-biased nature of technological upgrading in DCs. For example, adopting a cross-country perspective, Meschi and Vivarelli (2009) found that trade flows with more technologically advanced countries worsen income distribution by increasing wage differentials between skilled and unskilled workers. By the same token, Conte and Vivarelli (2011) report evidence of a positive relationship between the imports of industrial machinery, equipment, and ICT capital goods and the demand for skilled labor in low and middleincome countries. Almeida (2009) reaches similar conclusions when studying eight East-Asian middleincome countries, but does not find evidence supporting SBTC in low income countries. Raveh and Reshef (2015) study how the composition of capital imports affects relative demand for skill and the skill premium in a sample of DCs and find that, while capital imports per se do not influence the skill premium, their composition does. Their results in fact indicate that imports of R\&D-intensive capital equipment raise the skill premium, while imports of less innovative equipment lower it.

Turning to country specific studies, based on micro-data, Hanson and Harrison (1999) found that within each Mexican industry, firms that import machinery and materials are more likely to employ a higher share of white-collar workers than firms that do not import these inputs. Fuentes and Gilchrist (2005) using micro-data for Chilean firms, found a significant relation between the adoption of foreign technology, as measured by patent usage, and increased relative demand for skilled labor. On the other hand, Pavcnik (2003), finds that the increased relative demand for white-collar workers by Chilean plants in early 1980's cannot be attributed to the use of imported materials, once she controls for time-invariant plant characteristics. More recently, Fajnzylber and Fernandes (2009) study the effects of international integration on a cross-section of manufacturing plants in Brazil and China. They find that the use of imported inputs, exports and FDI are associated with higher demand for skilled workers in Brazil; however, the same is not true for China, where specialization in unskilled laborintensive productions turns out to compensate for the access to skill-biased technologies. A more recent paper that also takes the case of Brazil using a panel of manufacturing firms over the period 1997-2005, reaches similar conclusions that support the hypothesis of skill-enhancing trade and the fact that technology has played a significant role in up-skilling manufacturing labor in Brazil (Araujo,

\footnotetext{
${ }^{4}$ For theoretical and empirical analyses investigating the role of globalization and technology in affecting employment in the DCs, see also Lee and Vivarelli, 2004 and 2006a; Vivarelli, 2004).

5 See, for example, Robbins (1996), Sanchez-Paramo and Schady (2003), Attanasio, Goldberg, Pavcnik (2004) for Argentina, Brazil, Mexico, Chile, and Colombia, and Kijima (2006) for India.
} 
Bogliacino, and Vivarelli, 2011). Birchenall (2001) also attributes increased inequality in Colombia to SBTC resulting from trade liberalization and increased openness of the economy. Similar results are found for African countries, where Gorg and Strobl (2002) show that the use of technologically advanced foreign machinery in Ghana has led to an increase in the demand for skilled labor. Edwards (2004), analyzing firm-level data in South Africa, finds convincing evidence that skill-enhancing trade (as reflected in diffusion of computers, FDI and import of intermediate inputs) has raised the skill intensity ratio in South-African manufacturing.

Finally, Meschi, Taymaz and Vivarelli (2011) study the effect of trade openness on inequality in Turkey. They conclude that both imports and exports contribute to raising inequality between skilled and unskilled workers due to the skill-biased nature of the technologies that are being imported and used in industries with export orientations.

In this paper we build upon the analysis in Meschi, Taymaz, Vivarelli (2011) by studying the effect of technology adoption not only on the wage bill share of skilled worker, but estimating separate equations that allow to evaluate the absolute vs relative nature of SBTC. Moreover, in this paper we distinguish between quantity and price effect, in the sense that we analyze separately the effect of trade and technology on employment and wages of skilled and unskilled workers. Finally, in this paper we rely on new data that allow identifying the possible labor-saving and skill-biased effect of firmlevel investments in foreign machinery and contrast it with the impact of domestically produced machinery investments.

\section{DATA AND DESCRIPTIVE STATISTICS}

This study uses data from the Turkish "Annual Manufacturing Industry Survey" conducted by the Turkish Statistical Institute, TurkStat. The survey covers 17,462 firms for the period between 1992 and 2001. The survey includes private firms having at least 10 employees as well as public ones, representing around $90 \%$ of the Turkish manufacturing output, within the formal sector.

The database provides a wide range of information on each firm including economic activity, size and composition of workforce, wages, purchases of input, volume of sales and output, investment activities, and the status of assets and capital. All monetary variables are expressed in 1994 Turkish Lira, using sector-specific deflators.

Interestingly, the dataset provides different firm-level measures to indicate technology adoption, which make the data particularly suitable for our analysis. In particular, we construct the following indicators: R\&D indicates the presence of internal R\&D expenditures to proxy domestic innovation capacity. Disembodied technology transfer from abroad is measured through a variable indicating whether the firm obtained royalties, patents, know-how and other property rights from abroad (PAT). Embodied technological change is captured by two variables that describe respectively the cumulative investment in domestically produced (INV_D) and foreign (imported) (INV_FOR) machinery and equipment per worker. The data also provide information on firms' international involvement, and we have information on whether firms export (EXP) and whether are foreign owned (FOR). 
Employment is measured as the number of workers per year. Workers are divided into two broad categories: (1) production workers, including technical personnel, foremen, supervisors and unskilled workers, and (2) administrative workers, including management and administration employees, and office personnel. This categorization is used in the empirical analysis to distinguish between whitecollar (skilled) workers proxied by the administrative workers, and blue-collar (unskilled) workers proxied by the production workers 6 .

The table below (Table 1) summarizes and defines all the variables included in the analysis

Table 1: Variables in the analysis and their definitions

\begin{tabular}{ll}
\hline Variable & Definition \\
\hline BC & Number of "blue collar" employees engaged in production activities \\
WC & Number of "white collar" employees engaged in non-production activities \\
BCW & Real wages of blue collar employees (total labor cost per worker) \\
WCW & Real wages of white collar employees (total labor cost per worker) \\
VA & Real value added of the firm \\
R\&D & Dummy variable for existence of R\&D activities \\
PAT & Dummy variable for obtaining foreign royalties, patents, know-how and other property rights \\
& from abroad \\
EXP & Dummy variable for export activities \\
FOR & Dummy for firms in which 10\% or more of capital is owned by foreigners \\
INV_D & Investment in domestically produced machinery and equipment per worker \\
INV_FOR & Investment in imported machinery and equipment per worker \\
\hline Note: & Annual observations for the period 1992 - 2001; all variables - apart from dummies - have \\
& been transformed into natural logarithms; source: Annual Manufacturing Industry Survey for \\
& the Republic of Turkey: TurkStat.
\end{tabular}

Table 2 reports the mean value of number of white and blue collars, their average wages and other relevant variables by types of firms, distinguishing by their exposure to domestic and foreign technology. The table shows that the firms that are more technologically advanced and those that are more involved in the international market, tend to have a higher share of white collars workers and higher wage gap between white and blue collars. These preliminary descriptive statistics are not in contrast with the hypotheses and the previous evidence discussed in Section 2.

\footnotetext{
${ }^{6}$ The decision to categorize skilled and unskilled labor based on this division stems from the fact that this approach has been widely used in the relevant literature, showing satisfactory results and a very strong correlation with the alternative classification based on educational attainments (see for example, Berman, Bound and Griliches, 1994; Leamer, 1998). Moreover, Meschi, Taymaz and Vivarelli (2011), using data from the Turkish Labor Force Survey on the composition and educational level of the Turkish manufacturing workforce, show that administrative employees are on average significantly more educated than production workers. In addition, the substantial wage differential between WC and BC workers is a further indication for skill differences.
} 
Table 2: Mean characteristics, by types of firms

\begin{tabular}{l|r|rrrr}
\hline Variables & All firms & $\begin{array}{c}\text { R\&D } \\
\text { performer } \\
\text { (R\&D=1) }\end{array}$ & $\begin{array}{c}\text { Technology } \\
\text { transfer } \\
\text { (PAT=1) }\end{array}$ & $\begin{array}{c}\text { Exporter } \\
\text { (EXP=1) }\end{array}$ & $\begin{array}{c}\text { Foreign } \\
\text { (FOR=1) }\end{array}$ \\
\hline Blue collar workers & 32 & 53 & 143 & 73 & 98 \\
White collar workers & 7 & 15 & 58 & 17 & 39 \\
$\quad$ White collar/Blue collar & 0.224 & 0.281 & 0.406 & 0.229 & 0.402 \\
Wage rate, blue collar & 72 & 94 & 190 & 93 & 182 \\
Wage rate, white collar & 97 & 135 & 339 & 136 & 335 \\
$\quad$ White collar/Blue collar & 1.35 & 1.44 & 1.78 & 1.46 & 1.84 \\
Real value added & 11379 & 33649 & 232806 & 47946 & 154250 \\
Value added per employee & 289 & 469 & 1083 & 508 & 1039 \\
R\&D performer & 0.122 & 1.000 & 0.453 & 0.220 & 0.338 \\
Technology transfer & 0.018 & 0.068 & 1.000 & 0.055 & 0.266 \\
Foreign & 0.032 & 0.088 & 0.459 & 0.082 & 1.000 \\
Foreign machinery share & 0.174 & 0.171 & 0.189 & 0.172 & 0.197 \\
Number of observations & 114577 & 14002 & 2109 & 20356 & 3639 \\
\hline
\end{tabular}

Notes: Level variables are calculated as plant level geometric averages, proportions as plant level simple averages. Non-missing number of observations vary by variable because of differences in non-item response rates.

\section{1: TRENDS IN EMPLOYMENT, WAGES AND TECHNOLOGICAL UPGRADING}

Our data show that during the sample period, overall employment has been increasing for both production and administrative workers (Fig.1). Production workers (plotted on the left axis) are about three time as numerous compared to administrative workers (right axis) and seem to face higher fluctuations, while the increase in administrative workers has been slightly more stable. In particular, the number of production workers increased by about 45\% from 1992 to 2001, while the number of administrative workers increased by about $41 \%$. Over the same period, the wage gap between skilled and unskilled workers has increased substantially (see figure 2), which suggests an upward shift in the relative demand for skilled labor. An increase in relative wages in a period in which relative employment remained nearly stable in fact implies an increase in the wage bill share of skilled workers and thus an increase in the demand for skilled workers? ${ }^{7}$.

7 Under the hypothesis of elasticity of substitution between skilled and unskilled labor equal to one, an increase in the wage bill share can be interpreted as an upward shift of relative labor demand for skilled workers (see Berman and Machin, 2000 and Berman et al., 2005). The wage bill share of skilled workers can be expressed as: $W B S H=\frac{w_{s} S}{w_{S} S+w_{l} L}=\frac{w_{s} S}{w E}$ where $w$ is wages, $s$ subscript denotes skilled labor, $l$ subscript denotes low-skilled labor, $\mathrm{S}$ and $\mathrm{L}$ are respectively the number of skilled and low-skilled workers and $\mathrm{E}$ is total employment. Taking the logarithm, the formula can be decomposed as follows: $\log (W B S H)=\log \left(w_{S} / w\right)+\log (S / E)$. If the elasticity of substitution between $\mathrm{S}$ and $\mathrm{L}$ is one, WBSH is constant along a relative demand curve, so that the log change in relative wages and that of relative employment sum to zero: $\Delta \log (W B S H)=\Delta \log \left(w_{s} / w\right)+\Delta \log (S / E)=0$. 
Figure 1: Evolution of employment of white-collars and blue-collars workers

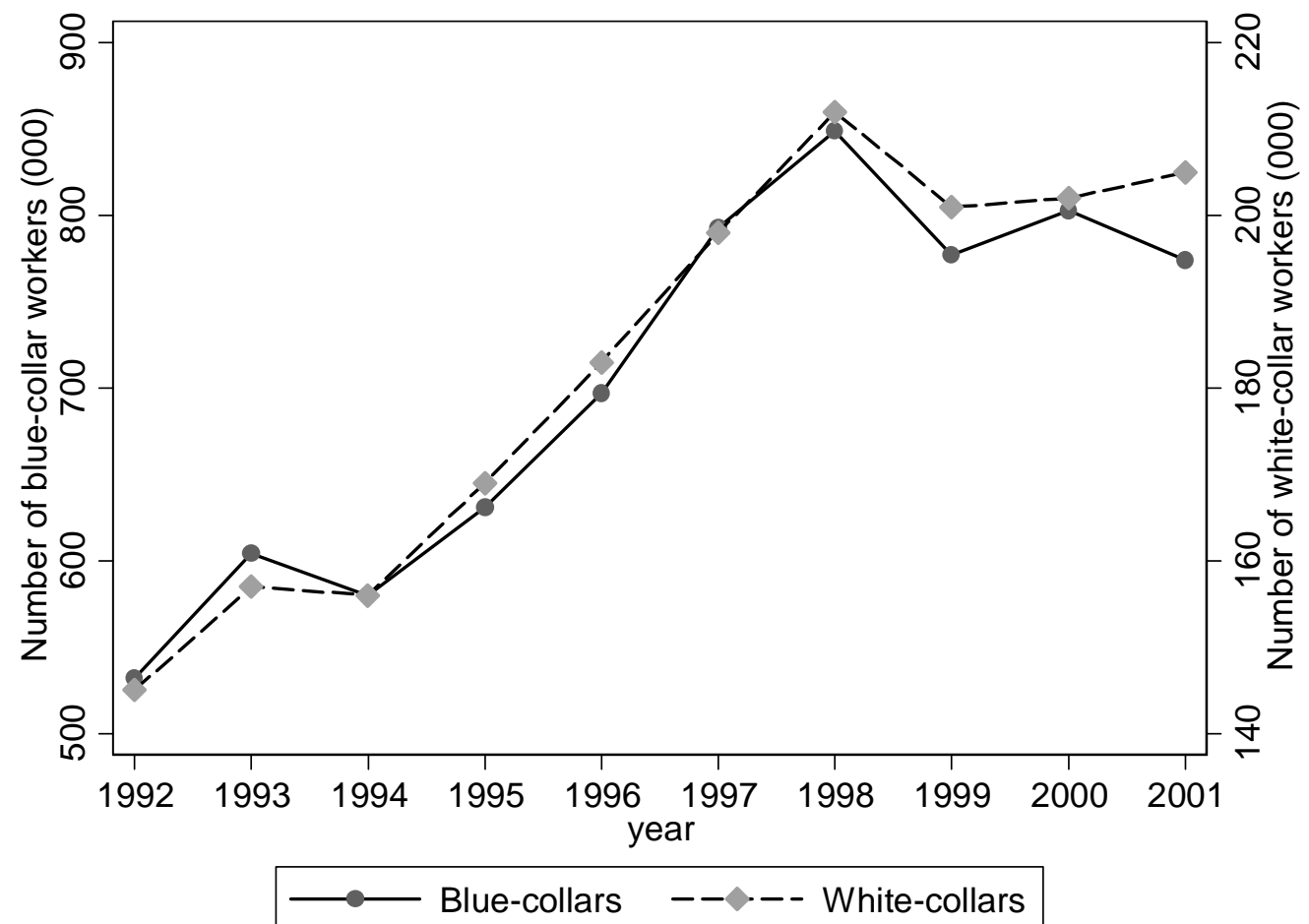

Source: Own elaborations from Annual Manufacturing Industry Survey, TurkStat

Figure 2: Evolution of wage gap between white-collars and blue-collar workers.

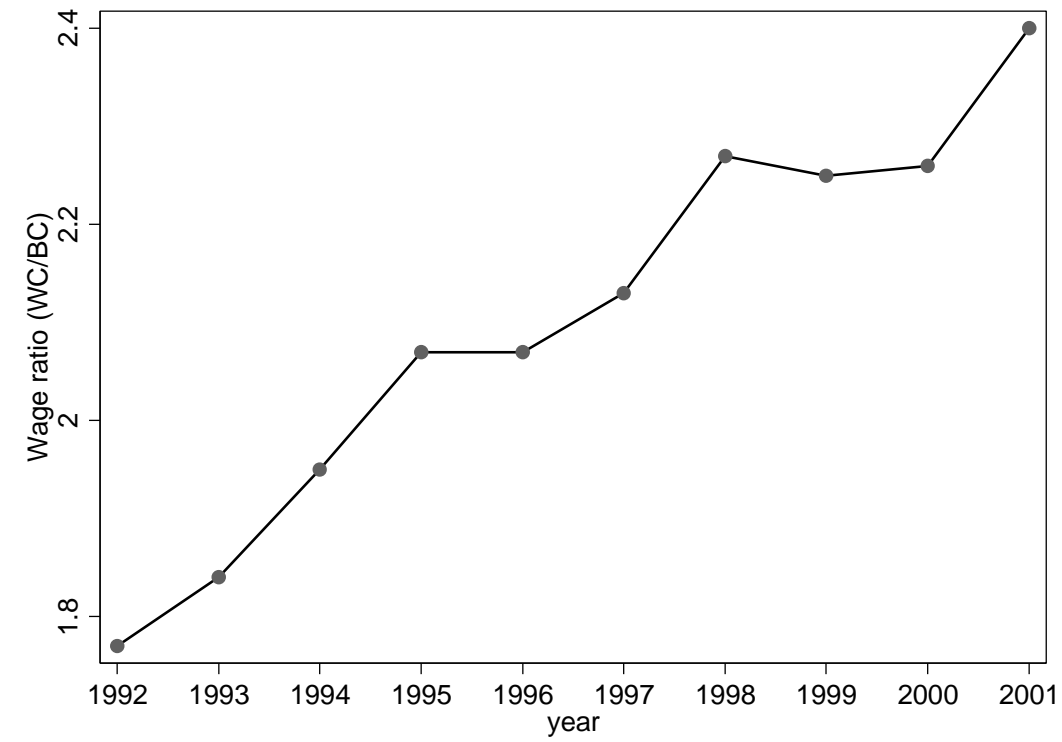

Source: Own elaborations from Annual Manufacturing Industry Survey, TurkStat

As documented in Meschi, Taymaz and Vivarelli (2011) such an increase was mainly driven by skill upgrading within industry (that represents more than 88 percent of the overall change) rather than between industries, which points at the relevance of the SBTC hypothesis. 
Indeed - over the period analyzed - the Turkish manufacturing sector was exposed to growing international competition and to a significant increase in trade flows ${ }^{8}$, which has favored technology adoption from abroad. Table 3 reports the evolution of the share of firms in the manufacturing sector performing R\&D (col. 1), receiving technological transfer (patents, royalties) from abroad (col 2), and the share of foreign-owned (col. 3) and exporter (col. 4) firms. Finally, Column 5 shows the share of foreign machinery on total capital investment. The table highlights that during the trade liberalization phase, Turkish manufacturing sector has been increasingly exposed to international technology that contributed to technological upgrading possibly more than domestic investment in R\&D9.

Table 3: Descriptive statistics on the Turkish manufacturing sector

\begin{tabular}{l|cccc|c}
\hline & \multicolumn{4}{|c|}{$\%$ of total firms } & \multirow{2}{*}{$\begin{array}{c}\text { Share of foreign } \\
\text { machinery }\end{array}$} \\
\hline & $\begin{array}{c}\text { R\&D } \\
\text { performer }\end{array}$ & $\begin{array}{c}\text { Technology } \\
\text { transfer }\end{array}$ & $\begin{array}{c}\text { Foreign- } \\
\text { owned }\end{array}$ & Exporter & \\
\hline 1992 & $8.1 \%$ & $1.5 \%$ & $2.4 \%$ & $13.8 \%$ & $73.0 \%$ \\
1993 & $12.4 \%$ & $1.6 \%$ & $2.8 \%$ & $17.7 \%$ & $78.3 \%$ \\
1994 & $14.7 \%$ & $1.7 \%$ & $3.0 \%$ & $19.5 \%$ & $81.4 \%$ \\
1995 & $15.8 \%$ & $1.8 \%$ & $3.1 \%$ & $21.0 \%$ & $83.6 \%$ \\
1996 & $13.8 \%$ & $1.9 \%$ & $3.1 \%$ & $16.6 \%$ & $84.3 \%$ \\
1997 & $13.1 \%$ & $2.0 \%$ & $3.2 \%$ & $12.6 \%$ & $85.3 \%$ \\
1998 & $13.3 \%$ & $1.8 \%$ & $3.3 \%$ & $17.9 \%$ & $86.2 \%$ \\
1999 & $14.1 \%$ & $1.7 \%$ & $3.6 \%$ & $19.2 \%$ & $87.7 \%$ \\
2000 & $14.6 \%$ & $2.0 \%$ & $3.7 \%$ & $20.6 \%$ & $88.9 \%$ \\
2001 & $11.7 \%$ & $2.3 \%$ & $3.7 \%$ & $19.5 \%$ & $89.4 \%$ \\
\hline
\end{tabular}

Source: Own elaborations from Annual Manufacturing Industry Survey, TurkStat.

Overall, we have seen that during the 1992-2001 period, Turkish manufacturing firms have experienced a phase of technological upgrading, mainly due to technology transfer from abroad and to the new technologies embodied in imported capital goods. Over the same period, the wage gap between skilled and unskilled workers has increased, suggesting a rising demand for skilled labor in the manufacturing sector. While these descriptive evidences are not in contrast with our interpretative hypotheses (see Section 2), we need to develop a micro-econometric approach to properly test them.

\footnotetext{
8 Until 1980, Turkish economic and trade policies were characterised by import-substituting industrialisation under heavy state protection. In January 1980, a comprehensive structural adjustment reform programme was launched and a major component of the reform package consisted in trade liberalisation policies. In 1989, the country opened up its domestic and asset markets to international competition with the declaration of the convertibility of the Turkish Lira in 1989 and the elimination of controls on foreign capital transactions. In 1996, Turkey signed the Custom Union agreement with the European Union and Free Trade Agreements with the European Free Trade countries, such as Central and Eastern European countries, and Israel. These policy changes led to significant increases in both imports and exports. For example, the import penetration ratio for manufacturing increased from 15 percent in 1980 to $30 \%$ in 2000 (Taymaz and Yilmaz, 2007).

${ }^{9}$ From a macroeconomic point of view, the Turkish gross domestic expenditure on R\&D (public and private) to GDP ratio has in fact increased over the investigated decade (from 0.49 in 1992 to 0.72 in 2001), but still falling much lower than the OECD average (see Elci, 2003).
} 
Indeed, the aim of the following empirical analysis is to investigate and quantify the role of domestic and trade-induced technological upgrading in explaining trends in labor demand, separately studying the effect on employment trends (quantity effect) and relative wages (price effect). Our empirical strategy and identification issues are discussed in the next section.

\section{THE EMPIRICAL MOdEL: SPECIFICATION AND ECONOMETRIC ISSUES}

Consistently with previous empirical literature, our estimating equation derives from a standard labor demand equation. In particular, following Van Reenen (1997), we consider a model in which firms operate under a constant elasticity of substitution production function (CES) of the form:

$$
Y=T\left[(A L)^{\frac{\sigma-1}{\sigma}}+(B K)^{\frac{\sigma-1}{\sigma}}\right]^{\frac{\sigma}{\sigma-1}}
$$

Where $\mathrm{Y}$ is the output, $\mathrm{L}$ and $\mathrm{K}$ represent conventional inputs such as labor and capital; $\mathrm{T}, \mathrm{A}$ and $\mathrm{B}$ are a Hicks-neutral, a labor-augmenting and a capital-augmenting technology respectively; the first-order profit-maximization condition for labor yields to:

$$
\log (L)=\ln (Y)-\sigma \log (W)+(\sigma-1) \log (\mathrm{A})
$$

We start from this standard framework and augment this equation replacing the unobserved technology variable A with proxies for innovation and technology adoption, and including variables describing firms' involvement in the international market (see Section 2).

If we consider two types of labor inputs, namely skilled (white-collars WC) and unskilled (blue-collars BC) and adopt a dynamic specification in order to account for adjustment costs that determine serial correlation in the employment series (see Van Reenen, 1997; Lachenmaier and Rottman, 2011; and Conte and Vivarelli, 2011), our estimating equations of the quantity effect are the following:

$$
\begin{aligned}
& \mathrm{BC}_{\mathrm{it}}=\rho \mathrm{BC}_{\mathrm{it}-1}+\delta_{1} \mathrm{BCW}_{\mathrm{it}}+\delta_{2} \mathrm{WCW}_{\mathrm{it}}+\gamma \mathrm{Y}_{\mathrm{it}}+\eta \mathrm{TECH}_{\mathrm{it}}+\mu \mathrm{OPEN}_{\mathrm{it}}+\lambda_{1} \mathrm{INV}_{-} \mathrm{D}_{\mathrm{it}}+\lambda_{2} \mathrm{INV}_{-} \mathrm{F}_{\mathrm{it}}+\tau_{\mathrm{t}}+\left(\mathrm{u}_{\mathrm{it}}+\varepsilon_{\mathrm{i}}\right) \\
& \mathrm{WC}_{\mathrm{it}}=\rho \mathrm{WC} \mathrm{C}_{\mathrm{it}-1}+\delta_{2} \mathrm{WCW}_{\mathrm{it}}+\delta_{1} \mathrm{BCW}_{\mathrm{it}}+\gamma \mathrm{Y}_{\mathrm{it}}+\eta \mathrm{TECH}_{\mathrm{it}}+\mu \mathrm{OPEN}_{\mathrm{it}}+\lambda_{1} \mathrm{INV}_{-} \mathrm{D}_{\mathrm{it}}+\lambda_{2} \mathrm{INV}_{-} \mathrm{F}_{\mathrm{it}}+\tau_{\mathrm{t}}+\left(\mathrm{u}_{\mathrm{it}}+\varepsilon_{\mathrm{i}}\right)
\end{aligned}
$$

All variables - apart from dummies - are expressed in natural logarithms. BC and WC are respectively the numbers of blue-collar and white-collar workers of firm $i$ at time $t$. BCW and WCW are the wages of each labor category. Each equation contains wages for both the categories of workers, since the price of both types of labor are likely to affect firms' hiring decisions. Y is firms' value added that reflects the impact of firms' sales and controls for possible business cycle fluctuations that can affect demand for the different types of labor. TECH is a vector composed of two dummy variables representing domestic and imported technology: namely, the presence of internal R\&D expenditures (R\&D) and the obtained availability of a foreign patent or other appropriability devices developed abroad (PAT). OPEN is a vector of two dummy describing firms' international involvement: in particular, EXP is a dummy that takes the value of one when the firm is an exporter and zero if it does not export, while FOR is a dummy equal to 1 if $10 \%$ or more of a firm's capital is owned by foreigners. To test the role of embodied technological change, we use two investment variables (INV_D and INV_F) 
which are respectively the cumulative investment in domestically produced machinery and equipment per worker and the cumulative investment in foreign (imported) machinery and equipment per worker. $\tau_{\mathrm{t}}$ are time dummy to control for unobserved common macroeconomic and cyclical shocks that may affect the demand for labor. Finally, standard to panel data analysis, the error term is composed by the idiosyncratic error component $\left(\mathrm{u}_{\mathrm{it}}\right)$ and the time invariant firm fixed effect component $\left(\varepsilon_{\mathrm{i}}\right)$.

Equations (3) and (4) can be seen as a twofold dynamic labor demand, where employment depends on output, investment and wages as traditionally assumed, but also on additional drivers such as domestic technology, imported technology, FDI and "learning by exporting" (see Section 2).

In order to test whether the coefficients of the variables of interest are significantly different for whiteand blue-collars, we jointly estimate equations (3) and (4), through a fully interacted model. This yields the same results as in (3) and (4), but allows computing the variance and covariance matrix between all the estimated coefficients, which in turn allows testing the difference in their magnitudes, through a battery of Wald tests.

Therefore, estimating equations (3) and (4) and testing the differences in coefficient magnitudes allow to assess the impact of technology and trade variables on relative employment, and permit to investigate the relative versus absolute skill bias. In more detail, a change in technology (or trade) would be absolutely biased toward skilled labor if it increases the number of skilled workers, while decreasing that of unskilled ones. A relative skill bias would instead appear when the coefficients for both skilled and unskilled workers are positive and significant but differ in magnitude, with the coefficients for the unskilled workers being significantly lower. Moreover, the estimation of two separate equations for white and blue collars (as opposed to the alternative strategy on estimating a single equation on the employment ratio) allows exploring the autoregressive dynamics of blue-collars and white collars workers separately.

In estimating equations (3) and (4), we can study the quantitative impact of trade and technology on employment. In order to test their impacts on wage differentials, thus studying the price effect, we also estimate two wage equations of the following form (where the variables are defined as in (3) and (4), FS stands for female share) ${ }^{10}$ :

$$
\begin{aligned}
& \mathrm{BCW}_{\mathrm{it}}=\rho \mathrm{BCW} \mathrm{W}_{\mathrm{it}-1}+\beta \mathrm{WCW}_{\mathrm{it}-1}+\gamma \mathrm{Y}_{\mathrm{it}-1}+\delta \mathrm{FS}_{\mathrm{it}}+\eta \mathrm{TECH}_{\mathrm{it}}+\mu \mathrm{OPEN}_{\mathrm{it}}+\lambda_{1} \mathrm{INV}_{-} \mathrm{D}_{\mathrm{it}}+\lambda_{2} \mathrm{INV}_{-} \mathrm{F}_{\mathrm{it}}+\tau_{\mathrm{t}}+\left(\mathrm{u}_{\mathrm{it}}+\varepsilon_{\mathrm{i}}\right) \\
& \mathrm{WCW}_{\mathrm{it}}=\rho \mathrm{WCW}_{\mathrm{it}-1}+\beta \mathrm{BCW}_{\mathrm{it}-1}+\gamma \mathrm{Y}_{\mathrm{it}-1}+\delta \mathrm{FS}_{\mathrm{it}}+\eta \mathrm{TECH}_{\mathrm{it}}+\mu \mathrm{OPEN}_{\mathrm{it}}+\lambda_{1} \mathrm{INV}_{-} \mathrm{D}_{\mathrm{it}}+\lambda_{2} \mathrm{INV}_{-} \mathrm{F}_{\mathrm{it}}+\tau_{\mathrm{t}}+\left(\mathrm{u}_{\mathrm{it}}+\varepsilon_{\mathrm{i}}\right)
\end{aligned}
$$

For both eqs. (3) and (4) and eqs. (5) and (6), the presence of firm-specific effects creates a correlation between the lagged dependent variable $\mathrm{BC}_{\mathrm{it}-1}$ (and $\mathrm{WC}_{\mathrm{it}-1}$ ) and the individual fixed effect $\mathrm{u}_{\mathrm{i}}$. Therefore, the dynamic specification implies a violation of the assumption of strict exogeneity of the estimators. In this context, the use of least squares will lead to inconsistent and upwardly biased estimates for the coefficient of the lagged dependent variable (Hsiao, 1986). The firm effects can be eliminated through the within-group estimator (or fixed effects estimator, FE). However, this leads to a downward bias of the estimated parameter of the lagged dependent variable (Nickell, 1981).

\footnotetext{
10 Assuming that markets are competitive, then the wage of each factor is given by the derivative of $\mathrm{Y}$ with respect to each factor BC and WC. As can be seen, eqs (5) and (6) include the female share (FS) as an additional control which may affect wage evolution (see, for example, Ilmakunnas and Maliranta, 2005; Heyman, Sjöholm and Tingvall, 2007). Finally, since wage can be seen as a component of firm's value added, Y has been lagged one period in the two wage equations to avoid endogeneity.
} 
Extensive econometric research has been done in order to obtain consistent and efficient estimators of the parameters in dynamic panel models. Almost all approaches include first transforming the original equations to eliminate the fixed effects and then applying instrumental variables estimations for the lagged endogenous variable. Andersen and Hsiao (1982) developed a formulation for obtaining consistent FE-IV (fixed effects - instrumental variables) estimators by resorting to first differencing in order to eliminate the unobserved fixed effects, and then using two lags and beyond to instrument the lagged dependent variable.

Efficiency improvements have been made to the Andersen and Hsiao model through the utilization of the GMM (Generalized Method of Moments) technique. Arrellano and Bond (1991) first resorted to GMM by using an instrument matrix that includes all previous values of the lagged dependent variable, so obtaining the GMM-DIFF estimator. However, The GMM-DIFF estimator has been found to be weak when (a) there is strong persistence in the time series, and/or (b) the time dimension and time variability of the panel is small compared with its cross-section dimension and variability (Bond et al., 2001). Blundell and Bond (1998) have performed an efficiency improvement to the GMM-DIFF by using additional level moment conditions and obtaining the system GMM or GMM-SYS model. Through these added moment conditions, the GMM-SYS uses all the information available in the data based on the assumption that $E\left(\Delta u_{i t} \varepsilon_{i}\right)=0$ (Blundell and Bond, 1998; Bond, 2002). Since our panel dataset is characterized by both the above conditions (a) and (b), we adopted a GMM-SYS model.

\section{RESULTS AND DISCUSSION}

Before looking into the results of the regression estimations, there are some results from tests and complementary regressions that deserve to be briefly discussed.

First, we test autocorrelation in our panel using the test proposed by Wooldridge (2002) and the F-test statistic always rejected the null hypothesis of no autocorrelation at $1 \%$ level, which calls for a dynamic specification.

Secondly, the presence of a lagged dependent variable required running an OLS regression to determine the upper bound for the value of the coefficient obtained in the GMM-SYS. The OLS outcomes reported in Table A1 in appendix (columns 1 and 3) indeed show that the values of the coefficients of the lagged dependent variables from GMM-SYS (Table 4) are lower than those obtained from OLS. Similarly, the Fixed Effects (FE) methodology (columns 2 and 4 in Table A1) was applied to provide a lower bound for the value of the estimated coefficient of the lagged dependent variable in the GMM-SYS estimates, since the fixed effects lead to downward biased results. Also in this case, GMM-SYS results are consistent with the expectations. Overall, the comparison between GMM-SYS on the one hand and OLS and FE on the other hand is supporting the adequacy of the chosen GMM-SYS methodology. Results are discussed with reference to the preferred GMM-SYS specification proposed in Table 4, although they are generally consistent across the three methodologies (see Table A1).

A number of further tests were performed to test the validity of the estimated model and the robustness of the corresponding results. A Wald test ${ }^{11}$ was run to test for the overall joint significance of the independent variables: it always rejects the null hypothesis of insignificant coefficients. The

11 It is distributed as a $\chi 2$ where the degrees of freedom equate the number of restricted coefficients. 
Hansen test for over-identifying restrictions was also performed: the null of adequate instruments was actually rejected in both the employment and wage equations, only for blue-collar workers. However, since it has been demonstrated that the Hansen test over-rejects the null in case of very large samples (see Blundell and Bond, 1999; Roodman, 2006), the same model was run and the Hansen test performed on a random sub-sample comprising $20 \%$ of the original data. The outcome was that the Hansen tests never rejected the null, so reassuring on the validity of the chosen instruments ${ }^{12}$. Finally, the standard Arellano and Bond (AR) tests for autocorrelation support the consistency of the adopted GMM estimators, however only after using t-3 instruments.

Looking at employment equations (col. 1 and 2, Table 4), the positive and highly significant values of the lagged coefficients for both types of workers confirm the persistence of the employment timeseries. Also consistent with our expectations, the wage coefficients are in line with the standard requirement for the relationship between wages and labor demand. In particular, the labor demand for a specific category of workers turns out to be negatively correlated with the wage rate of the corresponding category, while positively correlated with the wage rate of the alternative category.

As expected, firms' value added has a positive impact on both blue collar and white-collar workers, indicating that expansion of production requires higher demand for both types of labor.

By contrast, investment in domestic machinery implies a labor saving effect, especially for blue collars. This is in line with the view according to which the introduction of new machines (that is a way to introduce process innovation) may cause job losses (see Section 2.1). Interestingly enough, blue-collar workers, directly involved in factory production, are those that are more likely to be displaced by new machinery.

However, this labor-saving effect appears to be confined to domestic investment. In fact, we get different results when we turn our attention to investment in foreign machinery, which tends to stimulate employment of both white and blue-collar workers. While the employment effect is not significantly different between white and blue-collars (see table 5), we find that foreign technology embodied in capital goods leads to a widening of wage differentials between skilled and unskilled workers. Columns 3 and 4 of Table 4 in fact report that investment in foreign machinery tends to increase the wages of white collars more than those of blue-collars (and the difference is statistically significant, as shown in Table 5). Since the technological content of imported capital is likely more advanced than that embodied in domestic capital, we interpret this finding as a support of the SET hypothesis (see Section 2.2).

Turning our attention to the variables describing disembodied technological change (R\&D and patents) and international openness (EXP and FOR), they all seem to have an employment enhancing effect. This means that no negative employment quantitative impacts emerge because of technological change, which implies that labor-friendly product innovation (captured by R\&D and PAT) and compensation mechanisms have been effective in Turkish manufacturing, at least over the investigated period (see Section 2.1) .

12 Results available from the authors upon request. 
Table 4: Employment and wage equations for unskilled and skilled workers; GMM-SYS estimates.

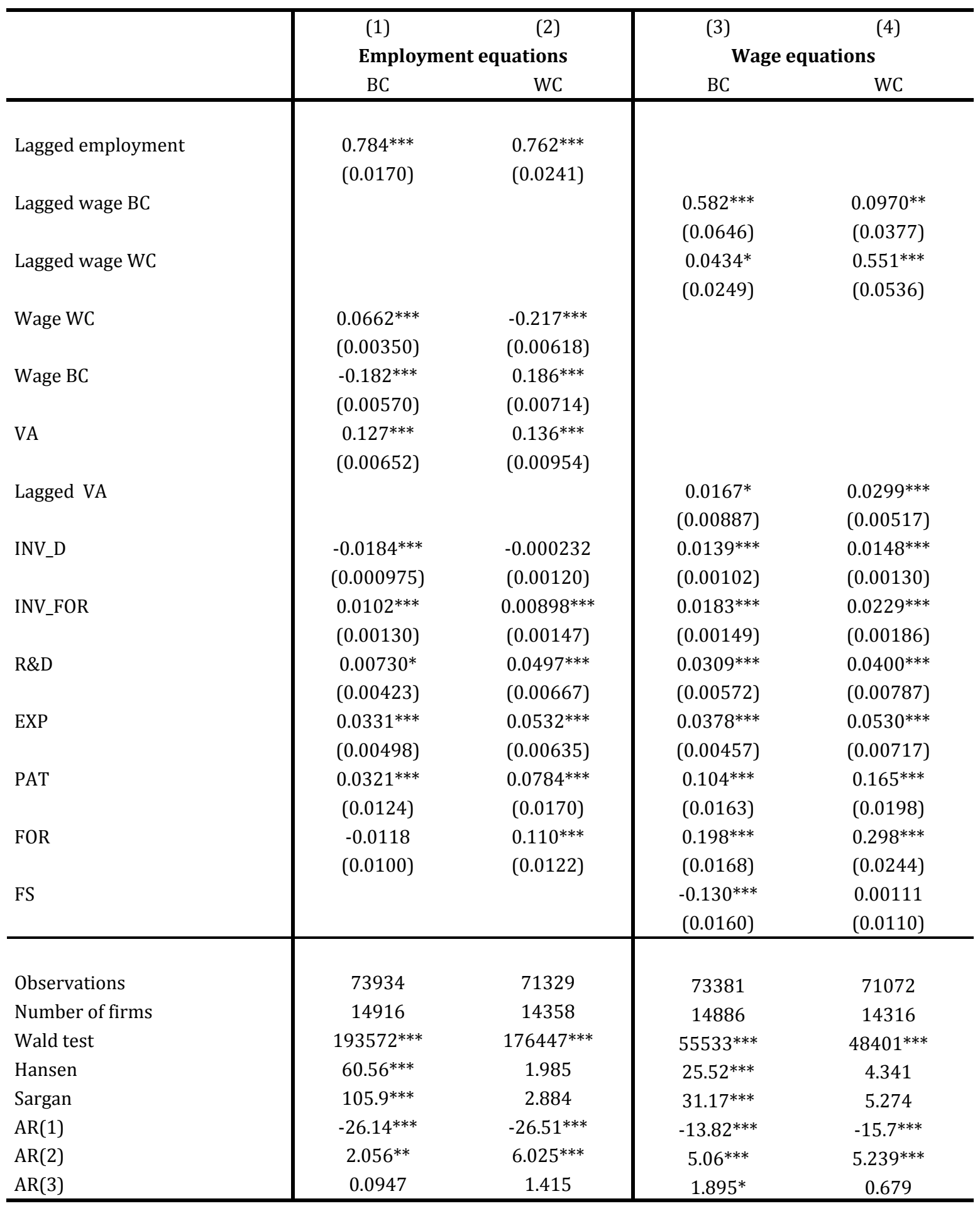

Notes: Robust standard errors in parentheses; *** indicates $\mathrm{p}<0.01$; $^{* *} \mathrm{p}<0.05$; $^{*} \mathrm{p}<0.1$.

The number of firms reported in the table refers to firms whose data are used in estimating the model. Since all models include the lagged value of the dependent variable and take the difference of variables to run GMM estimates, a firm is included if it has at least three consecutive observations. This has implied the drop from 17,462 companies to less than 15,000 .

However, for both the technological variables, we detect a relative skill bias, since they favor more the skilled workers rather than the low skilled ones: indeed, the coefficients for white-collars are significantly higher than those for blue-collars in both the employment and wage equation (the relevant tests are displayed in Table 5). 
Focusing on the variables describing firms' involvement in international markets, the results concerning EXP (pointing to a relative skill bias) is supporting the "learning by exporting" hypothesis (see Section 2.2). Looking at the variable FOR, which identifies firms partially foreign-owned, we see that receiving FDI increases the demand for skilled labor, and implies an absolute skill bias. FDI in fact increase the employment of white-collars, while do not significantly affect the employment of blue collars. In the wage equations, we also see that FDI amplify the wage gap between skilled and unskilled workers. This is consistent with the idea that FDI can be an important conduit for the transfer of skillbiased technologies (see Section 2.2).

Overall, our results strongly support both the SBTC and the SET hypotheses: indeed, both domestic and foreign technologies have fostered the demand for skilled workers in Turkish manufacturing. This means that opening up to international trade and the resulting technological upgrading, while increasing employment and possibly productivity, may also have a worrying effect on skill dispersion and wage inequality.

Table 5: Wald test statistics for the null hypothesis of equal coefficients for BC and WC

\begin{tabular}{lcc}
\hline Variable & $\begin{array}{c}\text { Labor demand } \\
\text { equation }\end{array}$ & $\begin{array}{c}\text { Wage } \\
\text { equation }\end{array}$ \\
\hline Local investment & $145.61^{* * *}$ & 0.08 \\
Foreign investment & 0.56 & $5.27^{* *}$ \\
R\&D performer & $27.35^{* * *}$ & 0.76 \\
Exporter & $5.54^{* *}$ & $4.69^{* *}$ \\
Technology transfer & $4.44^{* *}$ & $5.85^{* *}$ \\
Foreign & $59.62^{* * *}$ & $12.56^{* * *}$ \\
\hline
\end{tabular}

Note: ${ }^{* * *} \mathrm{p}<0.01 * * \mathrm{p}<0.05^{*} \mathrm{p}<0.1$

The significance of the difference in the coefficients for white- and bluecollars was tested jointly estimating equations (3) and (4), and (5) and (6) through a fully interacted model.

\section{CONCLUDING REMARKS}

This paper has empirically explored the possible roles of trade and technology in affecting employment skills and wages within the Turkish manufacturing sector over the two decades of the '80s and '90s, a period of increasing globalization for the Turkish economy.

A first outcome from this study is that the interlinked relationship between technology and trade positively contributed to employment creation in Turkish manufacturing (this means that compensation did work, at least in Turkish manufacturing over the investigated period, see Section 2.1). A notable exception is the domestic investment in new machineries that exhibits an obvious labor-saving impact, although limited to the blue collar workers. 
A second important outcome is that a strong evidence of a relative skill bias emerges: indeed, domestic R\&D activities, imported technologies, and export increase the demand for skilled labor significantly more than the demand for the unskilled. Finally, FDI imply an absolute skill bias.

On the whole, this evidence offers a strong support to the Skill-Biased-Technological-Change (SBTC) hypothesis and points out the key roles that the skill-enhancing-trade (SET), "learning by exporting" and FDI may play in shaping the demand for labor in a developing country (see Section 2.2).

The fact that technology and globalization imply an obvious skill-bias calls for economic policies in DCs able to couple trade liberalization with education and training policies targeted to increase and to better shape the local supply of skilled labor.

\section{REFERENCES}

Acemoglu, D. (1998.) Why do new technologies complement skills? Directed technical change and wage inequality. The Quarterly Journal of Economics, 113, 1055-1089.

Acemoglu, D. (2003). Patterns of skill premia. Review of Economic Studies, 70, 199-230.

Aguirregabiria, V., \& Alonso-Borrego, C. (2001). Occupational structure, technological innovation, and reorganization of production. Labor Economics, 8(1), 43-73.

Almeida, R. (2009). Openness and technological innovation in East Asia: have they increased the demand for skills?. IZA Discussion Papers N.4474, Institute for the Study of Labor (IZA), Bonn.

Anderson TW, Hsiao C. (1982). Formulation and estimation of dynamic models using panel data. Journal of Econometrics, 18, 47-82.

Ansal, K.H, \& Karaomelioglu D.C (1999). New technologies and employment: industry and firm level evidence from Turkey. New Technology, Work and Employment, 14, 82-167.

Araújo B.C., Bogliacino F., \& Vivarelli M. (2011). Technology, trade and skills in Brazil: some evidence from microdata. CEPAL Review, 105, 157-171.

Arellano, M. \& Bond, S. (1991). Some tests of specification for panel data: Monte Carlo evidence and an application to employment equations. Review of Economic Studies, 58, 277-297.

Attanasio, O., Goldberg P., and N. Pavcnik (2004): "Trade Reforms and Wage Inequality in Colombia," Journal of Development Economics, 74, 331-366.

Autor, D., Katz, L. \& Krueger, A. (1998). Computing inequality: have computers changed the labor market?. Quarterly Journal of Economics, 113, 1169-1214.

Becker, S. O., Ekholm, K. \& Muendler, M.-A. (2013). Offshoring and the onshore composition of tasks and skills. Journal of International Economics, 90, 91-106.

Berman, E., Bound, J. \& Griliches, Z. (1994). Changes in the demand for skilled labor within U.S. manufacturing industries. Quarterly Journal of Economics, 109, 367-398.

Berman, E. \& Machin, S. (2000). Skill-Biased technology transfer around the World. Oxford Review of Economic Policy, 16, 12-22.

Berman, E. \& Machin, S. (2004). Globalization, Skill-Biased Technological Change and Labor Demand. In Lee, E. and Vivarelli, M. (Eds) Understanding Globalization, Employment and Poverty Reduction (pp. 39-66). New York: Palgrave Macmillan. 
Birchenall, J.A., (2001). Income distribution, human capital and economic growth in Colombia. Journal of Development Economics, 66, 271-287.

Blomström, M. and Kokko, A. (1998): "Multinational Corporations and Spillovers", Journal of Economic Surveys, Vol. 12, pp. 247-277.

Blundell, R. \& Bond, S. (1998). Initial conditions and moment restrictions in dynamic panel data models. Journal of Econometrics, 87, 115-43.

Blundell, R. \& Bond, S. (1999). GMM Estimation with persistent panel data: an application to production functions. IFS Working Papers no. 99/04. London: Institute for Fiscal Studies

Bogliacino, F. \& Pianta, M. (2010). Innovation and employment. A reinvestigation using revised Pavitt classes. Research Policy, 39, 799-809.

Bogliacino, F. \& Vivarelli, M. (2012). The job creation effect of R\&D expenditures. Australian Economic Papers, 51, 96-113.

Bogliacino, F., Piva M. \& Vivarelli, M., (2012). R\&D and employment: An application of the LSDVC estimator using European data, Economics Letters, 116, 56-59.

Bond, S. (2002), Dynamic panel data models: a guide to micro data methods and practice. CEMMAP Working Paper no. CWP09/02. London: Centre for Microdata Methods and Practice.

Bond, S; Hoeffler A, \& Temple, J. (2001). GMM estimation of empirical growth models. CEPR Discussion Paper no. 3048. London: Centre for Economic Policy Research.

Bustos, P. 2011. "Trade Liberalization, Exports, and Technology Upgrading: Evidence on the Impact of MERCOSUR on Argentinian Firms." American Economic Review, 101(1): 304-40.

Coe, D.T. and Helpman, E. (1995). International R\&D Spillovers, European Economic Review, 39, pp. 859-88

Conte, A. \& Vivarelli, M. (2011). Globalization and employment: imported skill biased technological change in developing countries. The Developing Economies, 49, 36-65.

Dosi, G. \& Nelson, R.R. (2013). The evolution of technologies: an assessment of the state-of-the art. Eurasian Business Review, 3, 3-46.

Edwards, L. (2004). A firm level analysis of trade, technology and employment in South Africa, Journal of International Development, 16, 45-61.

Elci, S. (2003). Innovation policy profile: Turkey. Enterprise Directorate-General Contract $\mathrm{N}^{\circ}$ INNO-0206. Study coordinated by ADE.

Falk, M. \& Seim, K., (1999). Workers' skill level and information technology: evidence from German service firms. ZEW Discussion Papers 99-14, ZEW - Zentrum für Europäische Wirtschaftsforschung / Center for European Economic Research.

Fajnzylber, P. \& Fernandes, A. (2009). International economic activities and skilled demand: evidence from Brazil and China. Applied Economics, 41, 563-577.

Feldmann, H. (2013). Technological unemployment in industrial countries. Journal of Evolutionary Economics, 23, 1099-1126.

Fuentes, 0. \& Gilchrist S. (2005). Trade orientation and labor market evolution: evidence from Chilean plant-level data. In J. Restrepo and Tokman, A. (Eds), Labor Markets and Institutio. Central Bank of Chile, Santiago.

Gallego, F. A., 2012. "Skill Premium in Chile: Studying Skill Upgrading in the South," World Development, vol. 40(3), pp. 594-609.

Griliches, Z. (1969). Capital-skill Complementarity. Review of Economics and Statistics, 51, 465-68.

Görg, H. \& Strobl, E. (2002). Relative wages, openness and skill-biased technological change. IZA 
Discussion Papers N. 596, Institute for the Study of Labor (IZA).

Goux, D., \& Maurin, E. (2000). The decline in demand for unskilled labor: An empirical analysis methods and its application to France. The Review of Economics and Statistics, 82(2), 596-607.

Haskel, J., \& Heden, Y. (1999). Computers and the demand for skilled labor: Industry and establishment-level panel evidence from the United Kingdom. Economic Journal, 109(454), C68-79.

Hanson, G. and Harrison, A. (1999). Trade and wage inequality in Mexico. Industrial and Labor Relations Review, 52, 271-288.

Head, K. \& Ries, J. (2002). Offshore production and skill upgrading by Japanese manufacturing firms. Journal of International Economics, 58, 81-105.

Heyman, F., Sjöholm, F. and Tingvall, P.G. 2007. "Is There Really a Foreign Ownership Wage Premium? Evidence from Matched Employer-employee Data." Journal of International Economics 73 (2): 355-76.

Hsiao, C. (1986). Analysis of panel data. New York: Cambridge University Press.

Ilmakunnas, P., and Maliranta, M. 2005. "Technology, Labour Characteristics and Wage-Productivity Gaps" Oxford Bulletin of Economics and Statistics 67 (5): 623-45.

Keller, W. (2004): “International technology diffusion”, Journal of Economic Literature, Vol. 42(3), pp. 752-782.

Kijama, Y. (2006). "Why did wage inequality increase? Evidence from urban India 1983-99," Journal of Development Economics, 81, 97-117

Lachenmaier, S. \& Rottman, H. (2011). Effects of innovation on employment: a dynamic panel analysis. International Journal of Industrial Organization, 29, 210 -220.

Leamer, E. (1998). In search of Stolper-Samuelson effects on US wages. In Collins, S. (Eds). Imports, Exports and the American Worker (pp. 141-214). Washington D.C.: Brookings Institution Press.

Lee, E. \& Vivarelli, M. (2004) (eds). Understanding Globalization, Employment and Poverty Reduction. New York: Palgrave Macmillan.

Lee, E. \& Vivarelli, M. (2006a) (eds). Globalization, Employment and Income Distribution in Developing Countries. New York: Palgrave Macmillan.

Lee, E. \& Vivarelli, M. (2006b). The social impact of globalization in the developing countries. International Labor Review,145, 167-184.

Machin, S. (1996). Wage inequality in the UK. Oxford Review of Economic Policy, 12(1), 47-64.

Machin, D. (2003). The changing nature of labor demand in the new economy and skill-biased technology change. Oxford Bulletin of Economics \& Statistics, 63-S1, 753-776.

Machin, S., \& J. Van Reenen. (1998). Technology and changes in skill structure: evidence from seven OECD countries. Quarterly Journal of Economics, 113, 1215-44.

Mairesse, J., Greenan, N., \& Topiol-Bensaid, A. (2001). Information technology and research and development impact on productivity and skills: Looking for correlations on French firm level data. NBER Working Paper No. 8075. Cambridge, Massachusetts: National Bureau of Economic Research.

Marx, K. (1961). Capital. (First edition 1867). Moscow: Foreign Languages Publishing House.

Meschi, E. \& Vivarelli, M. (2009). Trade and income inequality in developing countries. World Development, 37, 287-302.

Meschi E., Taymaz E., \& Vivarelli, M. (2011). Trade, technology and skills: evidence from Turkish microdata, Labor Economics, 18, S60-S70.

Nickell, S. (1981). Biases in dynamic models with fixed effects. Econometrica, 49, 1417-1426.

Ozcelik, E. \& Taymaz, E. (2008). R\&D support programs in developing countries: the Turkish 
experience. Research Policy, 37, 258-275.

Pack, H. (2000). Research and development in the industrial development process. In L. Kim, \& R. R. Nelson (Eds.), Technology, learning and innovation. Experiences of newly industrializing economies. Cambridge: Cambridge University Press.

Pamukcu, T. (2003). Trade liberalization and innovation decisions of firms: lessons from post-1980 Turkey. World Development, 31, 1443-1458.

Pavcnik, N. (2003). What explains skill upgrading in less developed countries?. Journal of Development Economics, 71, 311-328.

Pianta, M. (2005). Innovation and Employment. In J. Fagerberg, D. Mowery and R. Nelson (Eds), Handbook of Innovation (Chapter 22). Oxford: Oxford University Press.

Piva, M., \& Vivarelli, M. (2004). Technological change and employment: some micro evidence from Italy. Applied Economic Letters, 11, 373-376.

Piva, M., \& Vivarelli, M. (2009), The role of skills as a major driver of corporate R\&D. International Journal of Manpower, 30, 835-852.

Raveh, O. and Reshef, A. (2015) . Capital Imports Composition, Complementarities, and the Skill Premium in Developing Countries. Journal of Development Economics, forthcoming.

Revenga, Ana. (1997). Employment and wage effects of trade liberalization: the case of Mexican manufacturing. Journal of Labor Economics 15 , part 2, S20-S43.

Robbins, D. (1996). HOS hits facts: facts win; evidence on trade and wages in the developing World. OECD Technical Paper No. 119.

Robbins, D. (2003). The impact of trade liberalization upon inequality in developing countries: a review of theory and evidence. Working Paper no. 13. Geneva: International Labor Organization.

Rodrik, D. (1995). Trade strategy, investment and exports: another look at East Asia. NBER Working Paper, No. 5339, Cambridge, MA.

Roodman D. (2006). How to Do xtabond2: An Introduction to "Difference" and "System" GMM in Stata. Working Papers 103, Center for Global Development.

Sanchez-Paramo, C. and N. Schady (2003): "Off and Running? Technology, Trade, and the Rising Demand for Skilled Workers in Latin America," World Bank Policy Research Working Paper 3015.Washington, DC: World Bank.

Stiglitz, J., (2002): Globalisation and its Discontents, Oxford: Oxford University Press.

Taymaz E. (1999). Trade liberalization and employment generation: the experience of Turkey in the 1980's. In A. Revenga (eds), Turkey: Economic Reforms, Living Standards, and Social Welfare Study, vol. 2 Technical Papers, Washington D.C : World Bank, 1998.

Taymaz E., \& Yilmaz K. (2007). Productivity and trade orientation: Turkish manufacturing industry before and after the customs union. The Journal of International Trade and Diplomacy, 1, 127 -154.

Van Reenen, J. (1997). Employment and technological innovation: evidence from UK manufacturing firms. Journal of Labor Economics, 15, 255-284.

Verhoogen, E. A. (2008). Trade, quality upgrading, and wage inequality in the Mexican manufacturing sector. Quarterly Journal of Economics, 123, 489-530.

Vivarelli, M. (1995). The Economics of Technology and Employment: Theory and Empirical Evidence. Aldershot: Elgar.

Vivarelli, M., (2004). Globalization, skills and within-country income inequality in developing countries. In E. Lee and M. Vivarelli (eds), Understanding Globalization, Employment and Poverty Reduction. New York: Palgrave Macmillan, 211-243. 
Vivarelli, M., 2013. Technology, employment and skills: an interpretative framework. Eurasian Business Review, 3, 66-89.

Vivarelli, M. (2014), Innovation, Employment, and Skills in Advanced and Developing Countries: A Survey of the Economic Literature, Journal of Economic Issues, 48, 123-154.

Welch, F. (1970). Education in production. Journal of Political Economy, 78, 35-59.

Wood, A. (1994). North-South trade, employment, and inequality: changing fortunes in a skill-driven World. Oxford: Clarendon Press.

Wood, A. (1995). How trade hurt unskilled workers. Journal of Economic Perspectives, 9, 57-80.

Wood, A. (2000). Globalization and wage inequalities: a synthesis of three theories. Social Science Research Network, Working Paper No. 240458.

Wooldridge, J. M. 2002. Econometric Analysis of Cross Section and Panel Data. Cambridge, MA: MIT Press

Yeaple, S. R., (2005). A simple model of firm heterogeneity, international trade, and wages. Journal of International Economics, 65, 1-20. 


\section{APPENDIX}

Table A1: Employment and wage equations for unskilled and skilled workers; OLS and FE estimates.

\begin{tabular}{|c|c|c|c|c|c|c|c|c|}
\hline & \multicolumn{4}{|c|}{ Employment equations } & \multicolumn{4}{|c|}{ Wage equations } \\
\hline & \multicolumn{2}{|c|}{ BC } & \multicolumn{2}{|c|}{ WC } & \multicolumn{2}{|c|}{ BC } & \multicolumn{2}{|c|}{ WC } \\
\hline & $O L S$ & $F E$ & $O L S$ & $F E$ & $O L S$ & $F E$ & $O L S$ & $F E$ \\
\hline Lagged employment & $\begin{array}{c}0.843^{* * *} \\
(0.00174)\end{array}$ & $\begin{array}{c}0.467^{* * *} \\
(0.00331)\end{array}$ & $\begin{array}{c}0.790^{* * *} \\
(0.00209)\end{array}$ & $\begin{array}{c}0.362^{* * *} \\
(0.00363)\end{array}$ & & & & \\
\hline Lagged wage rate BC & & & & & $\begin{array}{c}0.614^{* * *} \\
(0.00334)\end{array}$ & $\begin{array}{c}0.153^{* * *} \\
(0.00430)\end{array}$ & $\begin{array}{c}0.278^{* * *} \\
(0.00463)\end{array}$ & $\begin{array}{c}0.115^{* * *} \\
(0.00616)\end{array}$ \\
\hline Lagged wage rate WC & & & & & $\begin{array}{c}0.117^{* * *} \\
(0.00255)\end{array}$ & $\begin{array}{l}0.0439 * * * \\
(0.00301)\end{array}$ & $\begin{array}{c}0.509^{* * *} \\
(0.00358)\end{array}$ & $\begin{array}{c}0.104^{* * *} \\
(0.00433)\end{array}$ \\
\hline Wage rate $\mathrm{WC}$ & $\begin{array}{l}0.0423^{* * *} \\
(0.00231)\end{array}$ & $\begin{array}{l}0.0710^{* * *} \\
(0.00274)\end{array}$ & $\begin{array}{l}-0.151^{* * *} \\
(0.00326)\end{array}$ & $\begin{array}{l}-0.234^{* * *} \\
(0.00391)\end{array}$ & & & & \\
\hline Wage rate $\mathrm{BC}$ & $\begin{array}{l}-0.154 * * * \\
(0.00295)\end{array}$ & $\begin{array}{l}-0.158^{* * *} \\
(0.00388)\end{array}$ & $\begin{array}{c}0.125^{* * *} \\
(0.00412)\end{array}$ & $\begin{array}{c}0.146^{* * *} \\
(0.00553)\end{array}$ & & & & \\
\hline VA & $\begin{array}{c}0.109^{* * *} \\
(0.00130)\end{array}$ & $\begin{array}{c}0.132^{* * *} \\
(0.00180)\end{array}$ & $\begin{array}{c}0.136^{* * *} \\
(0.00176)\end{array}$ & $\begin{array}{c}0.115^{* * *} \\
(0.00253)\end{array}$ & & & & \\
\hline Lagged VA & & & & & $\begin{array}{l}0.0363^{* * *} \\
(0.00167)\end{array}$ & $\begin{array}{l}0.0174^{* * *} \\
(0.00216)\end{array}$ & $\begin{array}{l}0.0400^{* * *} \\
(0.00237)\end{array}$ & $\begin{array}{l}0.0147^{* * *} \\
(0.00312)\end{array}$ \\
\hline INV_D & $\begin{array}{l}-0.0104^{* * *} \\
(0.000609)\end{array}$ & $\begin{array}{c}-0.0436^{* * *} \\
(0.00141)\end{array}$ & $\begin{array}{c}0.00137 \\
(0.000861)\end{array}$ & $\begin{array}{c}-0.0211^{* * *} \\
(0.00202)\end{array}$ & $\begin{array}{l}0.00626^{* * *} \\
(0.000684)\end{array}$ & $\begin{array}{l}0.0111^{* * *} \\
(0.00158)\end{array}$ & $\begin{array}{l}0.00832 * * * \\
(0.000967)\end{array}$ & $\begin{array}{c}0.00698^{* * *} \\
(0.00228)\end{array}$ \\
\hline INV_FOR & $\begin{array}{l}0.00665^{* * *} \\
(0.000612)\end{array}$ & $\begin{array}{l}0.00263^{* *} \\
(0.00130)\end{array}$ & $\begin{array}{l}0.00363^{* * *} \\
(0.000857)\end{array}$ & $\begin{array}{l}0.0105^{* * *} \\
(0.00185)\end{array}$ & $\begin{array}{l}0.00951^{* * *} \\
(0.000659)\end{array}$ & $\begin{array}{c}0.00556^{* * *} \\
(0.00146)\end{array}$ & $\begin{array}{c}0.0145^{* * *} \\
(0.000921)\end{array}$ & $\begin{array}{l}0.0136^{* * *} \\
(0.00209)\end{array}$ \\
\hline $\mathrm{R} \& \mathrm{D}$ & $\begin{array}{c}0.00353 \\
(0.00337)\end{array}$ & $\begin{array}{l}0.0147^{* * *} \\
(0.00390)\end{array}$ & $\begin{array}{l}0.0487^{* * *} \\
(0.00476)\end{array}$ & $\begin{array}{l}0.0323^{* * *} \\
(0.00554)\end{array}$ & $\begin{array}{l}0.0297^{* * *} \\
(0.00379)\end{array}$ & $\begin{array}{c}0.0109^{* *} \\
(0.00438)\end{array}$ & $\begin{array}{l}0.0408^{* * *} \\
(0.00531)\end{array}$ & $\begin{array}{c}0.00758 \\
(0.00627)\end{array}$ \\
\hline EXP & $\begin{array}{l}0.0193^{* * *} \\
(0.00308)\end{array}$ & $\begin{array}{l}0.0262^{* * *} \\
(0.00409)\end{array}$ & $\begin{array}{l}0.0397^{* * *} \\
(0.00432)\end{array}$ & $\begin{array}{l}0.0516^{* * *} \\
(0.00580)\end{array}$ & $\begin{array}{l}0.0230^{* * *} \\
(0.00341)\end{array}$ & $\begin{array}{l}0.0295^{* * *} \\
(0.00458)\end{array}$ & $\begin{array}{l}0.0556^{* * *} \\
(0.00472)\end{array}$ & $\begin{array}{l}0.0219^{* * *} \\
(0.00654)\end{array}$ \\
\hline PAT & $\begin{array}{c}0.0103 \\
(0.00838)\end{array}$ & $\begin{array}{l}0.0301^{* *} \\
(0.0136)\end{array}$ & $\begin{array}{c}0.0513^{* * *} \\
(0.0117)\end{array}$ & $\begin{array}{l}0.0414^{* *} \\
(0.0191)\end{array}$ & $\begin{array}{l}0.0579 * * * \\
(0.00939)\end{array}$ & $\begin{array}{l}-0.00402 \\
(0.0152)\end{array}$ & $\begin{array}{l}0.123^{* * *} \\
(0.0130)\end{array}$ & $\begin{array}{l}0.00464 \\
(0.0215)\end{array}$ \\
\hline FOR & $\begin{array}{c}-0.0209^{* * *} \\
(0.00664)\end{array}$ & $\begin{array}{c}0.0542^{* * *} \\
(0.0147)\end{array}$ & $\begin{array}{l}0.0634^{* * *} \\
(0.00927)\end{array}$ & $\begin{array}{c}0.0724^{* * *} \\
(0.0207)\end{array}$ & $\begin{array}{c}0.121^{* * *} \\
(0.00745)\end{array}$ & $\begin{array}{c}0.0229 \\
(0.0165)\end{array}$ & $\begin{array}{l}0.232^{* * *} \\
(0.0103)\end{array}$ & $\begin{array}{l}0.140^{* * *} \\
(0.0234)\end{array}$ \\
\hline FS & & & & & $\begin{array}{l}-0.116^{* * *} \\
(0.00552)\end{array}$ & $\begin{array}{c}-0.0465^{* * *} \\
(0.0122) \\
\end{array}$ & $\begin{array}{c}-0.0161^{* *} \\
(0.00697) \\
\end{array}$ & $\begin{array}{l}0.0386^{* * *} \\
(0.00968)\end{array}$ \\
\hline Observations & 73934 & 73934 & 71329 & 71329 & 73381 & 73381 & 71072 & 71072 \\
\hline R-squared & 0.91 & 0.388 & 0.878 & 0.248 & 0.706 & 0.308 & 0.641 & 0.22 \\
\hline Number of firms & 14916 & 14916 & 14358 & 14358 & 14886 & 14886 & 14316 & 14316 \\
\hline
\end{tabular}

